\title{
Effect of Chemical Pre-treatments on Bioethanol Production from Chlorella minutissima
}

\author{
Burcu Şerbetçioğlu Sert, Benan İnan and Didem Özçimen* \\ Faculty of Chemical and Metallurgical Engineering, Department of Bioengineering, Yildiz Technical University, Davutpasa \\ Campus, 34220 Esenler-Istanbul, Turkey \\ *Corresponding author: E-mail: ozcimen@yildiz.edu.tr
}

Received: 01-08-2017

\begin{abstract}
In recent years, algal bioethanol production comes into prominence as a trend towards sustainable development. Due to being sustainable energy source and environmental friendly, bioethanol production from algae is becoming increasingly popular all over the world. However, yield of bioethanol production from algae is lower than first generation feedstock's currently, and needs to be improved. In order to increase bioethanol yield, pre-treatments should be performed as cell disruption process on algal biomass. For this reason, researchers investigate the most appropriate pre-treatment method and its parameters for high yield bioethanol production from algae. In this study, cultivated Chlorella minutissima was utilized for bioethanol production. Effects of pre-treatment method (dilute acid and alkaline), chemical concentration, pre-treatment temperature and pre-treatment time on bioethanol yield were investigated. It was found that, the highest bioethanol yield was obtained as $18.52 \%$ with acid pre-treatment at pre-treatment temperature of $100{ }^{\circ} \mathrm{C}$ and pre-treatment time of 60 minutes.
\end{abstract}

Keywords: Bioethanol, biofuel, biomass, Chlorella minutissima, microalgae

\section{Introduction}

Increase in the world population and emerging industry cause an increase in energy demand which are met by fossil fuels. However, fossil fuel resources are exhausting from day to day, and this decline in the reserves increases the price of petroleum fuels because of political impacts. Negative effects of petroleum fuels on environment, increased greenhouse gas emissions and global warming cause countries to take action on this matter. In order to reduce the environmental problems, increase socio-economic development and provide sustainable energy, utilizing renewable energy technologies such as solar, wind, hydro, and biomass, has been considered. ${ }^{1}$ As a renewable energy source, biofuel is one of the promising alternatives to the fossil fuels. Today, bioethanol has been identified as the most widely used biofuel for transportation worldwide. ${ }^{2}$ Bioethanol is produced from sugars and starch-rich raw materials such as corn, wheat and sugarcane. It can be blended with gasoline in different ratios, and there are specially designed engines which can use $100 \%$ bioethanol. $^{2}$ Bioethanol has excellent fuel properties for spark ignition internal combustion engines because of its high octane and heat of vaporization. In comparison with gasoline, these properties make ethanol more efficient as a pure fuel. ${ }^{3}$ Currently, bioethanol production is mostly carried out with sugarcane and corn as first generation bioethanol feedstock. Still, it is merely meet the current demand, and there are many conflicts and debates about their sustainability due to the depletion of water sources and the use of arable land to produce biomass for bioethanol production. ${ }^{4,5}$ Although lignocellulosic biomass is an alternative source for first generation bioethanol feedstocks, it requires intensive labor and a high capital cost for processing. ${ }^{5}$ Algae are considered as third generation biofuel feedstock and capable of generating more organic carbon per hectare than terrestrial plants. Except Asia, algae avoid the food versus fuel argument since they are not a major food source. ${ }^{6}$ Biomass production of algae is $5-10$-times greater than that of land-based plants due to their more photosynthetic efficiency. ${ }^{5}$ Algae grow rapidly and can be easily grown in various aquatic environments such as fresh water, saline water or municipal waste water. Microalgae don't need structural biopolymers such as hemicellulose and lignin which are necessary for terrestrial plants. This simplifies the process of bioethanol production from microalgae. ${ }^{7} \mathrm{Mi}-$ croalgae which have high amount of starch such as Chlorella, Dunaliella, Chlamydomonas, Scenedesmus are very useful for bioethanol production. Like as other bioethanol feed- 
stocks, algae are pre-treated with various methods before fermentation process. Although there are different pre-treatment methods for different biomass sources such as physical, chemical, physio-chemical and biological pre-treatments, chemical pre-treatments are the most used techniques for pre-treatment of algal biomass. ${ }^{8}$ Chemical pre-treatments are easy to perform, and good conversion yields can be achieved with these pre-treatments in a short time. ${ }^{9}$ According to the BP statistical review of world energy-2016 report, ethanol production of the world is higher than biodiesel production..$^{10}$ In the last decade, the increase of the production of ethanol is quite remarkable, and due to the global warming and high oil prices, it is considered that the ethanol production will continue to increase. Although there are a lot of studies on biodiesel production from different type of microalgae species in the literature, researches on bioethanol production from microalgae are less. In this study, cultivation of $C$. minutissima was carried out in labscale reactor, and the growth of microalgae was monitored with optical density analysis. Obtained algal biomass was analyzed with various analytical methods. During the bioethanol production from C. minutissima, in order to compare the effect of pre-treatment methods on bioethanol yield, acid and alkaline pre-treatments were performed. Effects of concentration, pre-treatment temperature and pre-treatment time on bioethanol yield were also investigated. There is not any study which is on the bioethanol production from C. minutissima and the comparison of chemical pre-treatment methods in the literature. The results of this study will contribute to the further studies and industrial applications by determining the efficient pre-treatment conditions for bioethanol production from microalgae.

\section{Experimental Section}

\section{1. Materials}

C. minutissima microalgae was cultivated in Bioengineering Department of Ylldı Technical University. In the cultivation step, $\mathrm{BBM}$ culture media was prepared with $0.075 \mathrm{~g} \mathrm{~K}_{2} \mathrm{HPO}_{4}, 0.014 \mathrm{~g} \mathrm{KH}_{2} \mathrm{PO}_{4}, 0.075 \mathrm{~g} \mathrm{MgSO}_{4} 7 \mathrm{H}_{2} \mathrm{O}$, $0.09 \mathrm{~g} \mathrm{NaNO}_{3}, 0.025 \mathrm{~g} \mathrm{CaCl}_{3} \cdot 2 \mathrm{H}_{2} \mathrm{O}, 0.025 \mathrm{~g} \mathrm{NaCl}, 0.05 \mathrm{~g}$ EDTA- $\mathrm{Na}_{4}, 0.00498 \mathrm{~g} \quad \mathrm{FeSO}_{4} 7 \mathrm{H}_{2} \mathrm{O}, 0.01142 \mathrm{~g}_{3} \mathrm{H}_{3} \mathrm{BO}_{3}$, $0.232 \mathrm{mg} \mathrm{MnCl} \cdot 4 \mathrm{H}_{2} \mathrm{O}, 1.41 \mathrm{mg} \mathrm{ZnSO}{ }_{4} \cdot 7 \mathrm{H}_{2} \mathrm{O}, 0.252 \mathrm{mg}$ $\mathrm{CuSO}_{4} \cdot 5 \mathrm{H}_{2} \mathrm{O}, 0.192 \mathrm{mg} \mathrm{NaMoO} \cdot 5 \mathrm{H}_{2} \mathrm{O}$. All of these chemicals were supplied from Merck. As for the pre-treatments and analytical measurements, $\mathrm{KOH}$ (Merck) and $\mathrm{H}_{2} \mathrm{SO}_{4}$ (98\% concentrated, Merck), and $96 \%$ purity ethanol (Merck), phenol (Sigma-Aldrich) and D-Glucose (Sigma-Aldrich) were used, respectively. LB Broth (Merck) was supplied to use in fermentation step.

\section{2. Biomass Cultivation}

Cultures of the C. minutissima were firstly cultivated in $500 \mathrm{~mL}$ Erlenmeyer flasks in BBM medium at $\mathrm{pH} 7.8$ in a shaking incubator set to $150 \mathrm{rpm}$ at $25 \pm 3{ }^{\circ} \mathrm{C}$ under continuous illumination. In logarithmic phase of the cultures, $10 \%(\mathrm{v} / \mathrm{v})$ inoculum was transferred to the $20 \mathrm{~L}$ photobioreactor, and cultivation was carried out with working volume of $15 \mathrm{~L}$ at $27^{\circ} \mathrm{C}$ and $\mathrm{pH}$ 8.3. A pump was used for aeration of the culture medium. Bioreactor was exposed to six pink-fluorescent lamps continuously (4500 lux). Growth of the culture was monitored by optical density measurement. Samples were taken from the photobioreactor and analysed daily. The conductivity of the medium and $\mathrm{pH}$ were measured as $256 \mathrm{mS} / \mathrm{cm}$ and 8.2 , respectively. Harvested algae were centrifuged and dried in an oven for $24 \mathrm{~h}$ at $70{ }^{\circ} \mathrm{C}$.

\section{3. Pre-treatment of Microalgal Biomass}

Dried microalgal biomass was pre-treated to degrade cellulosic cell wall for accessing fermentable carbohydrate components. Acid pre-treatments were performed with $0.5 \mathrm{~N}, 1 \mathrm{~N}, 2 \mathrm{~N}, 3 \mathrm{~N}$ and $5 \mathrm{~N} \mathrm{H}_{2} \mathrm{SO}_{4}$ solutions at different temperatures $\left(100{ }^{\circ} \mathrm{C}, 120^{\circ} \mathrm{C}\right.$ and $\left.140{ }^{\circ} \mathrm{C}\right)$ and pre-treatment times (15, 30 and 60 minutes). Pre-treatment conditions were chosen according to the previous studies in the literature. In order to compare the effect of pre-treatment type on bioethanol yield, alkaline pre-treatments were also carried out. Alkaline pre-treatments were conducted with various concentrations of $\mathrm{KOH}$ solutions $(0.5 \%, 0.75 \%$, $1 \%, 1.5 \%$ and $2 \%(\mathrm{w} / \mathrm{v}))$ at the different pre-treatment temperatures $\left(80^{\circ} \mathrm{C}, 100{ }^{\circ} \mathrm{C}\right.$ and $\left.120^{\circ} \mathrm{C}\right)$ and pre-treatment times (15, 30 and 60 minutes). After pre-treatments, samples in flasks were cooled down to the room temperature. The liquid from pre-treatment was neutralized before the fermentation. $\mathrm{pH}$ was maintained at 4.8 by alkaline/ acid solutions.

\section{4. Bioethanol Production}

The day before the fermentation, $S$. cerevisia yeast was cultured in flask with LB medium at the temperature of $40{ }^{\circ} \mathrm{C}$ and $150 \mathrm{rpm}$ shaking speed. $3 \%(\mathrm{v} / \mathrm{v}$ ) of yeast was inoculated to the pre-treated samples and fermentation was carried out in an incubator set to $150 \mathrm{rpm}$ and $40^{\circ} \mathrm{C}$ for $48 \mathrm{~h} .5 \mathrm{ml}$ were taken from the samples to determine the concentration of bioethanol by gas chromatography (GC) analysis.

\section{5. Analytical Methods}

During the microalgae cultivation, optical density measurement of the culture was used to monitor the algal growth. Optical density was measured by using UV-visible spectrophotometer at $680 \mathrm{~nm}$. Productivity of $C$. minutissima was expressed as the specific growth rate $(\mu)$ and doubling time $\left(\mathrm{t}_{\mathrm{d}}\right)$ by using the Equation 1-2 from the cell density change during specific time period of exponential phase. $^{11}$ 


$$
\begin{aligned}
& \mu=\frac{\ln \frac{N(t)}{N(0)}}{t} \\
& t d=\frac{\ln 2}{\mu}
\end{aligned}
$$

Carbohydrate analysis, lipid analysis and protein analysis were carried out with Phenol-sulfuric acid method, Soxhlet Ethanol Extraction and Lowry method, respectively.

Characterization of C. minutissima was also performed with Fourier Transform Infrared spectroscopy (FTIR spectroscopy) and proximate analysis. Proximate analysis was performed with TA instrument (Q600 SDT) according to ASTM-E 1755-01 and ASTM-D E872-82 standards. FTIR spectroscopy was carried out with the instrument of Thermoscientific (Nicolet 6700) and functional groups were determined in the wavenumber range of an IR spectrum of $600-4000 \mathrm{~cm}^{-1}$.

YL 6100 GC gas chromatography was used to evaluate bioethanol concentration. Samples from fermentation process (at $24 \mathrm{~h}$ and $48 \mathrm{~h}$ ) were taken and prepared for GC instrument for further analysis. Firstly, samples were filtered using $0.45 \mu \mathrm{m}$ filters to avoid blocking in column. The GC gas chromatograph contains flame ionization detector (FID) and $30 \mathrm{~m} \times 0.32 \mathrm{~mm} \times 0.25 \mu \mathrm{m}$ ZB-FFAP column. The temperature of injector, detector and oven were maintained at $150{ }^{\circ} \mathrm{C}, 250^{\circ} \mathrm{C}$ and $100^{\circ} \mathrm{C}$, respectively. Hydrogen was used as carrier gas. Bioethanol concentration was calculated using calibration curve that was prepared by the different concentration of bioethanol standards $(0.1 \%-10 \%(\mathrm{v} / \mathrm{v}))$. The mean and standard deviations of the data were calculated, and data were presented as the mean of three.

\section{Results and Discussion}

\section{1. Growth of C. minutissima Microalgae}

Growth of C. minutissima was monitored by optical density measurement. Specific growth rate was calculated as 0.0879 day $^{-1}$ and the doubling time of the microalgal cells was calculated as 7.8 days in photobioreactor environment. Although there are studies in which microalgae have less doubling time than 7 days, it is a remarkable growth because the aeration may overwhelm stress in photobioreactor environment and microalgae may need more time to multiply according to Kawaroe et al. ${ }^{12} \mathrm{Lim}$ et al. also reported that doubling time of microalgae can be up to 6-7 days in $100 \mathrm{ml}$ of flask. ${ }^{13}$ Results of chemical composition and proximate analysis of $C$. minutissima were given in the Table 1, and FTIR analysis results were given in the Table 2 and Fig 1. As can be seen from the FTIR results given in Table 2, aliphatic CH stretching at $2922 \mathrm{~cm}^{-1}$ is caused by cycloparaffin structure. ${ }^{14} \mathrm{C}=\mathrm{C}$ ring stretching in bands between 1400 and $1600 \mathrm{~cm}^{-1}$ indicate presence of alkenes. ${ }^{15}$ Bands show that symmetrical and asymmetrical $\mathrm{C}-\mathrm{H}$ stretching linked to $-\mathrm{CH}_{2}$ group, derived from ali- phatic hydrocarbons and saturated aliphatic cyclic hydrocarbon. ${ }^{16} 1743 \mathrm{~cm}^{-1}$ band $(\mathrm{C}=\mathrm{O})$ indicates the presence of lipids, fatty acids and ester groups. The region from 1200 to $900 \mathrm{~cm}^{-1}$ signifies a sequence of bands due to $\mathrm{C}-\mathrm{O}, \mathrm{C}-\mathrm{C}$ and $\mathrm{C}-\mathrm{O}-\mathrm{C}$ stretching vibrations of polysaccharides.

Table 1. Chemical composition and proximate analysis of C. minutissima

\begin{tabular}{lllc}
\hline $\begin{array}{l}\text { Biochemical } \\
\text { Analysis }\end{array}$ & $\begin{array}{l}\text { Content } \\
\mathbf{( \% )}\end{array}$ & $\begin{array}{l}\text { Proximate } \\
\text { Analysis }\end{array}$ & $\begin{array}{l}\text { Content } \\
\mathbf{( \% )}\end{array}$ \\
\hline Carbohydrate & 33.05 & Ash & 9.39 \\
Protein & 24.69 & Moisture & 4.71 \\
Lipid & 42.26 & Volatile substance & 75.63 \\
& & Fixed carbon & 10.04 \\
\hline
\end{tabular}

Table 2. FTIR analysis of C. minutissima

\begin{tabular}{ll}
\hline $\begin{array}{l}\text { Wave } \\
\text { number } \\
\left(\mathbf{c m}^{-1}\right)\end{array}$ & Functional Groups \\
\hline 3275 & -OH stretching \\
2922 & Aliphatic CH stretching \\
1743 & C=O strecthing \\
1643 & Aromatic C=C ring stretching \\
1537 & Aromatic C=C ring stretching \\
1462 & CH stretching in methyl lipids \\
1398 & Aliphatical CH deformation \\
1274 & Aromatic CO- stretching \\
1257 & Aliphatic C-N stretching \\
1037 & Aliphatic ether C-O and alcohol C-O stretching \\
765 & 4 adjacent H deformation \\
\hline
\end{tabular}

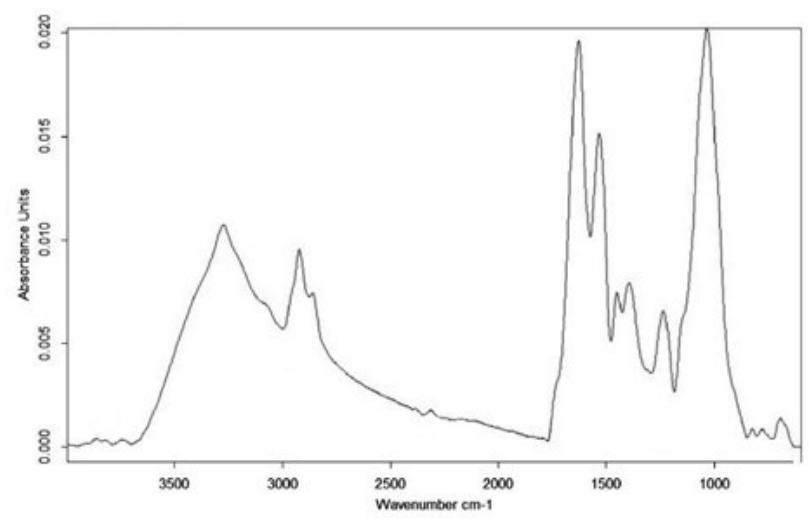

Fig 1. FTIR spectrum of C. minutissima

\section{2. Effect of Acid and Alkaline Concentrations on Bioethanol Production}

In order to investigate the effect of acid concentration on bioethanol yield, acid pre-treatments were performed with $0.5 \mathrm{~N}, 1 \mathrm{~N}, 2 \mathrm{~N}, 3 \mathrm{~N}$ and $5 \mathrm{~N} \mathrm{H}_{2} \mathrm{SO}_{4}$ solutions 
under the temperature of $100{ }^{\circ} \mathrm{C}$ and pre-treatment time of $60 \mathrm{~min}$. As can be seen in the Fig 2, bioethanol yields were obtained between $2.92-4.78 \%$ for $24 \mathrm{~h}$ and $5.26-18.52 \%$ for $48 \mathrm{~h}$ fermentation time. It was found that bioethanol yield increases up to a certain acid concentration. The highest bioethanol yield was obtained under $1 \mathrm{~N} \mathrm{H}_{2} \mathrm{SO}_{4}$ acid concentration. Above $1 \mathrm{~N} \mathrm{H}_{2} \mathrm{SO}_{4}$ bioethanol yields decreased with $2 \mathrm{~N}, 3 \mathrm{~N}$ and $5 \mathrm{~N}$ acid pre-treatments. It is considered that toxic components such as furaldehyde, acetate and hydroxymethylfuraldehyde may occur due to the effect of acid pre-treatment, and they inhibit the fermentation. ${ }^{17}$ Decrease in bioethanol yield in high acid concentrations of pre-treatment was observed. In the study of pre-treatment of Sargassum spp. with $1.0-5.0 \%(\mathrm{~m} / \mathrm{v})$ $\mathrm{H}_{2} \mathrm{SO}_{4}$ it was found that the best result was obtained with $3.4-4.6 \%$ acid pre-treatment, and bioethanol yield decreased with increasing acid concentrations. ${ }^{18}$ In another study, Gracilaria sp. was pretreated with $0.05,0.1,0.3$ and $0.5 \mathrm{~N} \mathrm{H}_{2} \mathrm{SO}_{4}$ and the highest bioethanol yield was achieved with $1 \mathrm{~N}$ acid pre-treatment. ${ }^{19}$

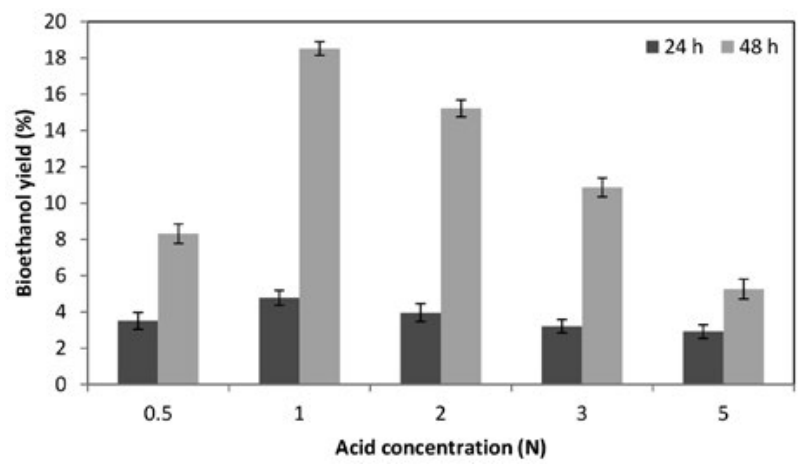

Fig 2. Bioethanol yields obtained from acid pre-treated (at $100{ }^{\circ} \mathrm{C}$, $60 \mathrm{~min}$ ) microalgae

Experimental data obtained under the conditions of $0.5 \%, 0.75 \%, 1 \%, 1.5 \%$, and $2 \%(\mathrm{w} / \mathrm{v}) \mathrm{KOH}$ solutions at $100{ }^{\circ} \mathrm{C}$ and 60 min were given in the Fig 3. It was determined that bioethanol yield was changed between 1.01$1.92 \%$ for $24 \mathrm{~h}$, and $\% 1.43-6.11 \%$ for $48 \mathrm{~h}$ fermentation time. The highest bioethanol yield was obtained with $0.75 \%(\mathrm{w} / \mathrm{v}) \mathrm{KOH}$ solution pre-treatment. Like as acid pre-treatment, a decrease was also observed with increasing alkaline concentrations above this concentration. In the literature, the highest bioethanol yield was achieved by pretreating Chlorococcum infusionum microalgae under the conditions of $0.75 \%(\mathrm{w} / \mathrm{v}) \mathrm{NaOH}$ pre-treatment.20 Also, this can be seen in alkaline pre-treatment of Ulva lactuca macroalgae collected from Marmara Sea. It was reported that, bioethanol productivity increased up to a certain concentration, and then it was started to decrease.21 The results obtained from this study are in agreement with these studies for bioethanol production. According to the results, it can be said that, acid pre-treatment is more efficient method than alkaline pre-treatment for algal biomass.

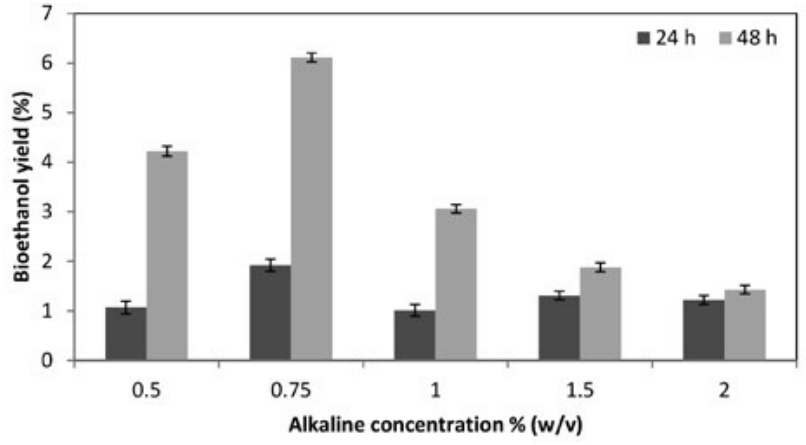

Fig 3. Bioethanol yield obtained after from alkaline pre-treated (at $100^{\circ} \mathrm{C}, 60 \mathrm{~min}$ ) microalgae

\section{3. Effect of Pre-treatment Temperature on Bioethanol Production}

Results obtained from the experiments performed at $100{ }^{\circ} \mathrm{C}, 120{ }^{\circ} \mathrm{C}$ and $140{ }^{\circ} \mathrm{C}$ with $1 \mathrm{~N}$ and $5 \mathrm{~N} \mathrm{H}_{2} \mathrm{SO}_{4}$ solutions for $60 \mathrm{~min}$, were given in Fig 4. As it was shown in the figure, bioethanol yield increased up to $120^{\circ} \mathrm{C}$ with both $1 \mathrm{~N}$ and $5 \mathrm{~N}$ pre-treatments. On the other hand, pre-treatments conducted at $140{ }^{\circ} \mathrm{C}$ resulted with a decrease in bioethanol yield. Bioethanol yield determined after pre-treatments carried out at high temperatures, increases up to a certain temperature and then, it decreases. This is due to the pre-treatments which change direct solubility of sugars and disrupt the structure of sugar based components. ${ }^{22}$ Generally, it is reported that, raw materials which contain lignin and hemicellulose, were pretreated at the temperatures above $160{ }^{\circ} \mathrm{C}$ with $0.5-1.5 \%(\mathrm{v} / \mathrm{v})$ acid solutions. ${ }^{23}$ In another study, corn fibers were pretreated with sulfuric acid at the temperatures of $120^{\circ} \mathrm{C}$ and $140{ }^{\circ} \mathrm{C}$ and $60 \mathrm{~min}$ pre-treatment time. It was observed that, yield of monomeric carbohydrates decreases with increasing pre-treatment temperatures. ${ }^{24}$ It is indicated in the literature, experiments should be performed under low pre-treatment temperature and acid concentrations when lignin content of raw materials are not high. Since structure of microalgae is simpler than other materials, it is assumed that monomeric carbohydrates are decomposed to toxic compounds at high temperatures.

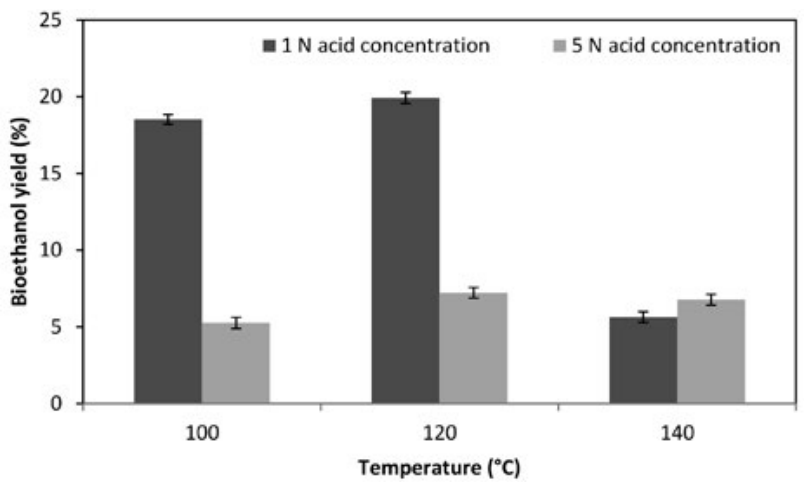

Fig 4. Effect of different acid pre-treatment temperatures on bioethanol yield 
Unlike acid pre-treatments, bioethanol yield increased up to $100^{\circ} \mathrm{C}$, then decreased at $120^{\circ} \mathrm{C}$ with $0.75 \%$ $(\mathrm{w} / \mathrm{v}) \mathrm{KOH}$ alkaline pre-treatment, however, it increased up to $120^{\circ} \mathrm{C}$ with $1.75 \%(\mathrm{w} / \mathrm{v}) \mathrm{KOH}$ alkaline pre-treatment (Fig 5). It is in agreement with the study carried out with Chlorococcum infosionum microalgae which were pretreated with $0.75 \%(\mathrm{w} / \mathrm{v}) \mathrm{NaOH}$ solution for $60 \mathrm{~min}$ at $80^{\circ} \mathrm{C}$ and $120^{\circ} \mathrm{C}$. In that study, bioethanol yields were obtained as $21.26 \%$ and $23.37 \%$, respectively. In higher concentrations of $\mathrm{NaOH}$, yield was determined as $23.75 \%$ at $80{ }^{\circ} \mathrm{C}$, and it decreased to $18.74 \%$ at $120^{\circ} \mathrm{C} .{ }^{20}$ Therefore, effect of different values of different parameters in the same time is variable and it can be said that it is difficult to assess a parameter alone independently.

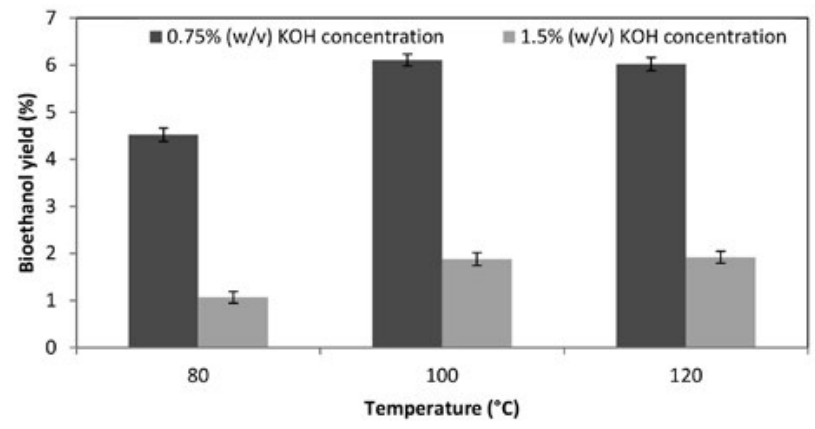

Fig 5. Effect of different alkaline pre-treatment temperatures on bioethanol yield

\section{4. Effect of Pre-treatment Time on Bioethanol Production}

In order to investigate the effect of different pre-treatment times on bioethanol production yield, $1 \mathrm{~N}$ and $5 \mathrm{~N}$ $\mathrm{H}_{2} \mathrm{SO}_{4}$ acid pre-treatments were carried out at the temperature of $120^{\circ} \mathrm{C}$ in the pre-treatment times of 15,30 and 60 minutes. According to Fig 6, increasing pre-treatment time increases bioethanol yield in both $1 \mathrm{~N}$ and $5 \mathrm{~N}$ acid pre-treatments. In the literature, the highest bioethanol yield was obtained for Scenedesmus obliquus microalgae under $2 \% \mathrm{H}_{2} \mathrm{SO}_{4}$ pre-treatment at $121{ }^{\circ} \mathrm{C}$ for $20 \mathrm{~min}^{25} \mathrm{In}$

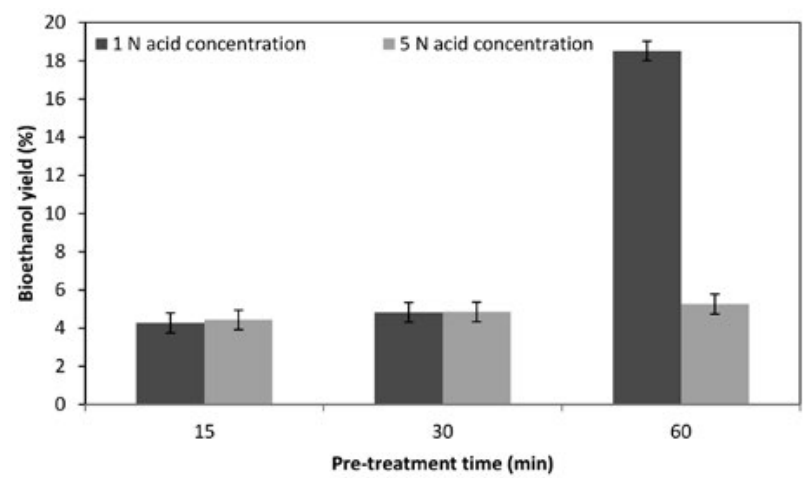

Fig 6. Effect of different acid pre-treatment times on bioethanol yield another study, corn cob was pretreated with $1 \% \mathrm{HCl}$ solution for $20-40 \mathrm{~min}$ at $100-130^{\circ} \mathrm{C}$, and it was observed that bioethanol yield increased with increasing pre-treatment time. ${ }^{26}$ This effect was also seen in the study of pretreating Kappaphycus alvarezii macroalgae with 1-1.5-2\% $\mathrm{H}_{2} \mathrm{SO}_{4}$ at $121{ }^{\circ} \mathrm{C}$ for 20,40 and $60 \mathrm{~min}$. It was found that the highest productivity was achieved with $1 \% \mathrm{H}_{2} \mathrm{SO}_{4}$ solution and 60 min pre-treatment time. ${ }^{23}$

Results of the experiments conducted at $100{ }^{\circ} \mathrm{C}$ for 15, 30 and 60 min with 0.75 and $1.5 \%$ (w/v) $\mathrm{KOH}$ solution were given in Fig 7. As can be seen in Fig 7, the highest yield was obtained under the conditions of $0.75 \%(\mathrm{w} / \mathrm{v})$ $\mathrm{KOH}$ solution for $60 \mathrm{~min}$. On the other hand, the highest yield was obtained with $15 \mathrm{~min}$ using $1.5 \%(\mathrm{w} / \mathrm{v}) \mathrm{KOH}$ solution. Results of bioethanol yields were similar for 15$30 \mathrm{~min}$ pre-treatments under the condition of $0.75 \%(\mathrm{w} / \mathrm{v})$ $\mathrm{KOH}$ pre-treatment, however, it was observed that an increase was occurred after $60 \mathrm{~min}$. On the other hand, bioethanol yield decreased after 15 min pre-treatment time with $1.5 \%(\mathrm{w} / \mathrm{v}) \mathrm{KOH}$ pre-treatment. In the study which performs alkaline pre-treatment on Chlorococcum infusionum microalgae, bioethanol yield increased from $12.88 \%$ to $21.26 \%$ at $80{ }^{\circ} \mathrm{C}$ with the pre-treatment time of 30 and $60 \mathrm{~min}$ after the treatment of $0.75 \%(\mathrm{w} / \mathrm{v}) \mathrm{NaOH}$ solution. However a slight decrease was seen at $120^{\circ} \mathrm{C}$ under the same pre-treatment time. After the treatment of $2 \%(\mathrm{w} / \mathrm{v}) \mathrm{NaOH}$ solutions, small increases and decreases were observed at the temperatures of $80^{\circ} \mathrm{C}$ and $120^{\circ} \mathrm{C}$ for 30 and 60 min. ${ }^{20}$

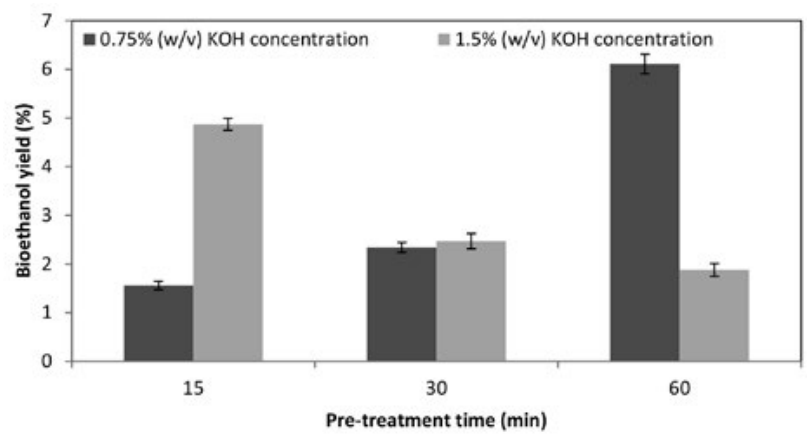

Fig 7. Effect of different alkaline pre-treatment times on bioethanol yield

\section{Conclusion}

In this study, C. minutissima was cultivated for bioethanol production, and applications of acid and alkaline pre-treatments were conducted before the fermentation, and effects of solution concentration, pre-treatment time and pre-treatment temperature on bioethanol yield were investigated. When acid pre-treatment was performed at $100{ }^{\circ} \mathrm{C}$ with $1 \mathrm{~N} \mathrm{H}_{2} \mathrm{SO}_{4}$ for 60 minutes, the highest bioethanol concentration was obtained as $18.52 \%$ which was almost three times higher than alkaline 
pre-treatment. Nowadays, algae are mostly utilized for biodiesel production due to their high lipid content. However, high operational costs lead the investigators to find new production methods or utilize algal biomass completely with biorefinery aspects. Algae have considerable carbohydrate content that cannot be ignored. Bioethanol production from algae is a technology ongoing in the last decade and open to development. Nevertheless, innovative and efficient fermentation processes and pre-treatment techniques are still needed to make ethanol production preferable.

\section{Acknowledgement}

The authors acknowledge financial support from the Yildız Technical University Scientific Research project (2015-07-04-YL03) provided for this work.

\section{References}

1. D. Özçimen, A. Ersoy-Meriçboyu, Fuel Process. Technol. 2008, 89(11), 1041-1046. DOI:10.1016/j.fuproc.2008.04.006

2. A. Cesaro, V. Belgiorno, Energ, 2015, 8(8), 8121-8144. DOI: $10.3390 /$ en 8088121

3. J. Yu, T. Tan, Fuel Process. Technol. 2008, 89(11), 1056-1059. DOI:10.1016/j.fuproc.2008.04.008

4. M. Vohra, J. Manwar, R. Manmode, S. Padgilwar, S. Patil, J. Environ. Chem. Eng. 2014, 2(1), 573-584.

DOI:10.1016/j.jece.2013.10.013

5. R. Bibi, Z. Ahmad, M. Imran, S. Hussain, A. Ditta, S. Mahmood, A. Khalid, Renewable Sustainable Energy Rev., 2017, 71, 976-985. DOI:10.1016/j.rser.2016.12.126

6. J. M. M. Adams, G. Bleathman, D. Thomas, J.A. Gallagher, J. Appl. Phycol, 2017, 1-7.

7. R. P. John, G. S. Anisha, K. M. Nampoothiri, A.Pandey, Bioresour. Technol. 2011, 102(1): 186-193.

DOI:10.1016/j.biortech.2010.06.139

8. J. Zhao, L. Xia, Fuel Process. Technol. 2010, 91(12), 1807-1811. DOI:10.1016/j.fuproc.2010.08.002

9. J. Hill, E. Nelson, D. Tilman, S. Polasky, D. Tiffany, Proc. Natl. Acad. Sci. 2006, 103(30): 11206-11210.

DOI:10.1073/pnas.0604600103

10. BP Statistical Review of World Energy June 2016, https:// www.bp.com/content/dam/bp/pdf/energy-economics/statis- tical-review-2016/bp-statistical-review-of-world-energy2016-full-report.pdf, (assessed: February 01, 2017)

11. F. Widdel, Theory and measurement of bacterial growth. Di Dalam Grundpraktikum Mikrobiologie, 2007, 1-11. Retrieved from https://www.mpi-bremen.de/Binaries/Binary13037/Wachstumsversuch.pdf, (assessed: February 15, 2017)

12. M. Kawaroe, J. Hwangbo, D. Augustine, H. A. Putra, Aquaculture, Aquarium, Conservation \& Legislation-International Journal of the Bioflux Society (AACL Bioflux), 2015, 8(5).

13. D. K. Lim, S. Garg, M. Timmins, E.S. Zhang, S.R. Thomas-Hall, H. Schuhmann, P.M. Schenk, PLoS One, 2012, 7(7), 1-13 DOI:10.1371/journal.pone.0040751

14. J. A. Vieira Costa, M. G. de Morais, in A. Pandey, D. Lee, Y. Chisti, and C. Rsocol (Ed.): Biofuels From Algae, Elsevier, USA. 2014, pp.1-22.

15. T. Aysu, M. M. Küçük, Energ. 2014, 64, 1002-1025. DOI:10.1016/j.energy.2013.11.053

16. G. Y. Elbeyli, PhD Thesis, Yıldız Technical University, 2005, Istanbul, Turkey.

17. J. W. Lee, J. Y. Kim, H. M. Jang, M. W. Lee, J. M. Park, Bioresour. Technol. 2015, 182: 296-301

DOI:10.1016/j.biortech.2015.01.116

18. M. G. Borines, R. L. de Leon, J. L. Cuello, Bioresour. Technol. 2013, 138: 22-29. DOI:10.1016/j.biortech.2013.03.108

19. F. C. Wu, J. Y. Wu, Y. J. Liao, M. Y. Wang, L. Shih, Bioresour. Technol. 2014, 156: 126-131

DOI:10.1016/j.biortech.2014.01.024

20. R. Harun, W. S. Y. Jason, T. Cherrington, M. K. Danquah, Appl Energy. 2011, 88, 3464-3467. DOI:10.1016/j.apenergy.2010.10.048

21. Inan, B, Master's Thesis. Ylldiz Technical University, 2014, Istanbul, Turkey.

22. R. Harun, M. K. Danquah, Process Biochem., 2011, 46(1): 304-309. DOI:10.1016/j.procbio.2010.08.027

23. P. L. Hargreaves, C. A. Barcelos, A. C. Augusto da Costa, N. Pereira Jr., Bioresour. Technol. 2013, 134: 257-263. DOI:10.1016/j.biortech.2013.02.002

24. H. Noureddini, J. Byun, Bioresour. Technol. 2010, 101(3): 1060-1067. DOI:10.1016/j.biortech.2009.08.094

25. J. Lee, P. Li, J. Lee, H. J. Ryu, K. K. Oha, Bioresour. Technol. 2013, 127:119-125. DOI:10.1016/j.biortech.2012.09.122

26. S. Zu, W. Li, M. Zhang, Z. Li, Z. Wang, H. Jameel, H. Chang, Bioresour. Technol. 2014, 152: 364-370.

DOI:10.1016/j.biortech.2013.11.034

\section{Povzetek}

Zaradi okolju prijazne tehnologije postaja v zadnjih letih po vsem svetu vse bolj popularna proizvodnja bioetanola iz algne biomase. Žal so izkoristki v primerjavi z drugimi tradicionalnimi surovinami slabi, zato jih je potrebno izboljšati. Podobno kot pri prvi in drugi generaciji surovin za proizvodnjo bioetanola se izvajajo različne vrste predpriprav algne biomase. Na tem področju raziskovalci proučujejo primerno metodo in ustrezne parametre za visoke izkoristke. V predstavljeni raziskavi je bila za optimiranje predpriprave uporabljena biomasa alge Chlorella minutissima v kislem in bazičnem mediju. Proučevani so bili vplivi koncentracije kemikalij, temperature in časa na izkoristek proizvodnje etanola. Rezultati so pokazali, da je bil najvišji izkoristek dosežen s predpripravo v kislem mediju. 